\title{
Biology of A Dragaonfly Crocothemis Servilia Servilia Drury (Odonata: Libellulidae), A Predator of Paddy Pests in Kolhapur.
}

\author{
A. R. Bhusnar ${ }^{1}$, T. V. Sathe ${ }^{2}$ \\ ${ }^{l}$ Department of Zoology, Yashwantrao Chavan Warana Mahavidyalaya Warananagar. \\ ${ }^{2}$ Department of Zoology, Shivaji University Kolhapur 416004, India
}

\begin{abstract}
Crocothemis servilia servilia (Drury) (Odonata: Libellulidae) is biocontrol agent of paddy pests in Kolhapur region of Maharashtra. It predates on paddy jassid Nilaparvata sp., Paddy borer Chilo suppersalis (Walker) and Jowar stem a borer Chilo partellus (Swin). Therefore, biology of C. servilia servilia has been studied under laboratory conditions $\left(24 \pm{ }^{\circ} \mathrm{C}, 70-75 \% \mathrm{RH}\right.$ and $12 \mathrm{hr}$ Photo period). It completes its life cycle within 3 months, egg stage lasts for 18 days and nymphal period is 72 days. There are 12 instars, each has about 7 - 10 days duration. During nymphal period they feed on paramoecium, daphnia, redworms and mosquito larvae. Adult survives for 4 days without food. Mated female can lay about $140-150$ eggs in water body/water trough. A single mated female, an average can produce 142 adults under laboratory conditions.
\end{abstract}

Key Words: Biology, Dragonfly, Crocothemis servilia servilia, Biocontrol agent, Paddy Pests.

\section{Introduction}

Crocothemis servilia servilia (Drury) (Odonata: Libellulidae) is biocontrol agent of paddy pests in Kolhapur region of Maharashtra. It predates on pady Jassid Nilaparvata sp, paddy borer Chilo suppresallis (Walker) and Jowar sten borer Chilo partellus (Swin). Therefore, biology of C. servilia servilia has been studied under laboratory condition $\left(24 \pm{ }^{\circ} \mathrm{C}, 70-75 \% \mathrm{RH}\right.$ and $24 \mathrm{hr}$ photo period). Biology provides basic information for mass rearing of individual species. Dragonflies as biocontrol agents are to be mass reared for there utility in biocontrol programme of pests. Review of literature indicates that biology of Dragonflies has been rerely attempted except the work of Corbet (1980, 1999), Kumar (1972, 1973, 1978, 1979, 1980), Kulkarni (1999), Kakkassery (2004), Sahayaraj (2004) and Sathe \& Shinde (2008) etc. Keeping in view all above facts the present work was carried out.

\section{Materials And Methods}

Nymphs of C. servilia servilia have been collected from the water bodies of Shivaji University, campus and reared in laboratory condition $\left(24 \pm{ }^{\circ} \mathrm{C}, 65-70 \% \mathrm{RH}\right.$ and $2 \mathrm{hr}$ photo period) for adult formation on red worms and mosquito larvae. On emergence, adult males and females were separated and kept in rearing cage and identified consulting. Fraser (1934 and 1936). Later, exposed for mating in laboratory (20 feet x 10 feet 14 feet in length, width and hight respectively.) After mating females were allowed to lay their eggs in the water tank. After hatching the eggs first instar nymphs and second instar nymphs where reared in the plastic tub by providing paramoecium, Daphnia etc. as food. Later, the nymphs (naiads) have been reared in aquarium ( 3 feet length $\mathrm{x} 2$ feet width $\mathrm{x} 1$ feet height) by providing red worms and mosquito larvae and observations where taken on the nymphal (naiad) duration and later, adult longevity in the laboratory. Sufficient number of individuals were reared for conformation of life cycle studies. In control no food was provided to adults.

\section{Results}

The life history of this species is amphibiotic and has 3 stages viz. egg (Fig.-3), naiad (nymph) (Fig-45) and adult (Fig-1+2). Egg is rounded and bluish in colour, about $1.5 \mathrm{~mm}$ long and hatched within 15 to 18 days. Naiad is flat bodied, measuring about $2 \mathrm{~cm}$ in body length. Naiad shows labial mask for catching preys. It also shows rectal gills in abdomen. There are 12 instars; each has about 7-10 days duration. During nymphal period they feed on paramoecium red-worm, daphnia and mosquito larvae. Adults survived for 4 days without food. Single mated female laid 140-150 eggs in water body and produced on an average 142 adults under laboratory conditions.

According to Sathe \& Shinde (2008) the aquatic life of larvae varies greatly in length. The dragonflies belonging to the genus Lestes have shortest duration of about three months while, the larger dragonflies showed longer period, about one year to 3 years. According to them, "The life history of dragonfly is amphibiotic and has 3 stages, viz. egg, nymph (naiad) and adult." The larval stage is passed in watery environment and adults are terestrial. In the present form C. s. servila same situation is recorded regarding life stages and habitat i.e. life cycle contains egg, nymph (naiad) and adult and the individual is amphibiotic. According to Kakkassery (2004) 
robust naiads shows labial mask for catching prey, rectal gills are within abdomen. Similar modifications are noticed in C.s. servilaria.

Kumar and Prasad (1977) counted 830 eggs in N. chinensis in $55 \mathrm{~cm}^{2}$ leaf area of fern plant. According to Kumar and Prasad (1977) incubation period of egg varies from 5-40 to 80-230 days in tropical and temperature regions. Anax immaculifrons lay eggs endophytically in submerged leaves while Ictinogomplus rapax lays on tightly coiled filament at the pole and prevents the eggs swepting down stream (Corbet, 1980). Similarly, Burmagomphus sivalinkensis deposit eggs on the substance covered with gelationous material (Kumar, 1978).

According to Kakkassery (2004) the naiad of dragonfly pass through 10-20 stages. The naiad feed on small insects, fishes, tadpoles and redworms etc. Pre-reproductive adult stage lasted for few days to 2-3 months in some dragonflies and colour change to body has taken place within same sex or between sex and males became more colourful. In the present form also colour change taken place within the unmatured and matured sex and between sexes. Males were uniformly pink coloured and females with spots and light yellowish colorations. It can easily complete in life cycle in domestic water storage and consume mosquito larvae. Hence, this is good biocontrol agent of mosquitoes, Aedes eagypti.

\section{Conclusion}

i) C.s. servilia is rearable in domestic water.

ii) It has good potential to control Aedes eagypti mosquitoes.

iii) Need its utilization in Biological control of insect pests of economic importance.

\section{Acknowledgement}

Authors are thankful to Shivaji University, Kolhapur and Yashwantrao Chavan Warana Mahavidyalaya, Warananaagr, Kolhapur for providing facilities.

\section{References}

[1]. Corbet P. S. (1999): Dragonfly behaviour and ecology of Odonata Cornell University Press, New York 154 p.p.

[2]. Corbet P. S. (1980): Biology of Odonata - A. Rev. Ent. 25, 189-217.

[3]. Fraser F. C. (1934): The Fauna of British India, Odonata Tayler and Francies, London - II, xxiii + 398, 10 pt.

[4]. Fraser F. C. (1936): Fauna of British India, Vol.-3, Taylor and Francies, London Ltd. 4bp pp.

[5]. Kakkassery F. K. (2004): Dragonflies and damselflies in Biological control in Indian Insect Predators in Biological control. 61-77 pp, New Delhi.

[6]. Kulkarni P. P., Bastawade D. B. and S. S. Talmale. (1999): Predation of dragonflies Ictingomphus rapax (Rambur) and Pantala flaviscens (Fab.) (Odonata Anisoptera) by the giant wood spider, Nephila maculata (Fab.).

[7]. Kumar A. (1972): The life history of Lestes praemorse praemorse (Selys) (Odonata: Lestidae). Treubia, 28, 3-20.

[8]. Kumar A. (1973): Description of the last instar larvae of Odonata from the Dehra Dun Valley (India), with notes on biology-II (Suborder: Anisoptera). Oriental Ins, 7, 291-331.

[9]. Kumar A. (1978): Some field notes on the Odonata around a fresh water lake in western Himalaya. Entomon, 2, 225-230.

[10]. Kumar A. (1979): Studies on the life history of Indian dragonflies, Pseudagrion rubriceps Selys (Odonata: Coenagrionidae). Rec. Zool. Serv. India, 75, 371-381.

[11]. Kumar A. (1980): Studies on the life history of Indian dragonflies, Eriagrion coromandelianum (Fab.) (Odonata: Coenagrionidae). Rec. Zool. Surv. India, 76, 249-250.

[12]. Sathe T.V and A.R. Bhusnar (2010) Biodiversity of Mosquitovorus dragonflies (Order: Odonata) from Kolhapur district including Western Ghats. Biological forum.2 (2) 41.

[13]. Sathe T. V. and K. P. Shinde. (2008): Dragonflies and Pest Management pp 179. DPH New Delhi.

[14]. Sahayaraj N. (2004): Indian Insect predators in Biological control pp. 336. DPH New Delhi.

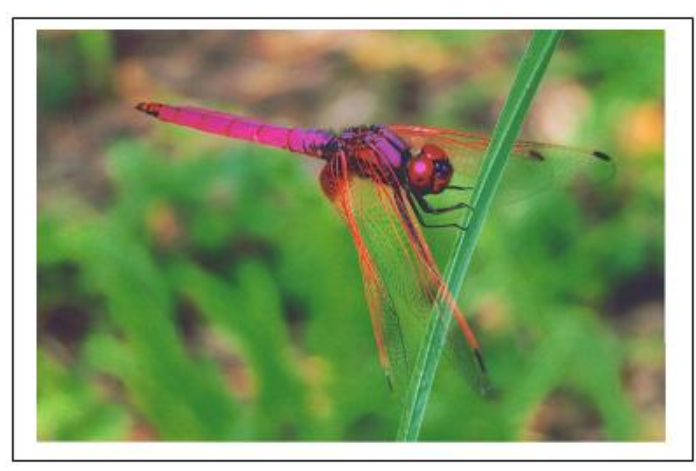

Fig. C. servilia servilia (Female)

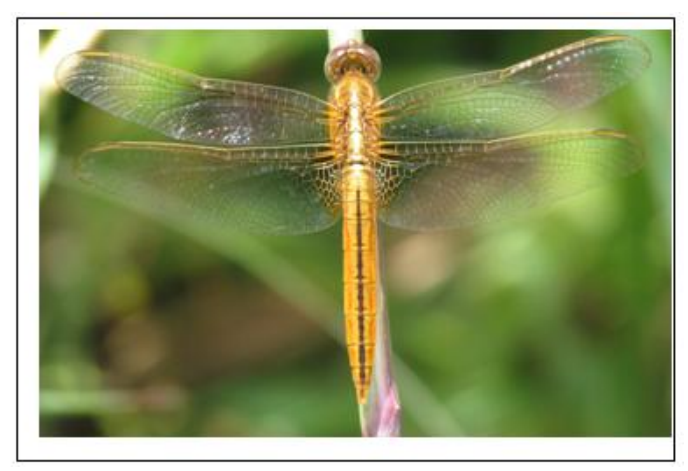

Fig. - 2: C. servilia servilia (Female) 


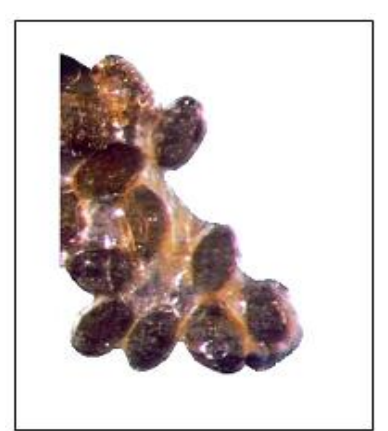

Fig.- 3:Eggs - C.s servilia servilia

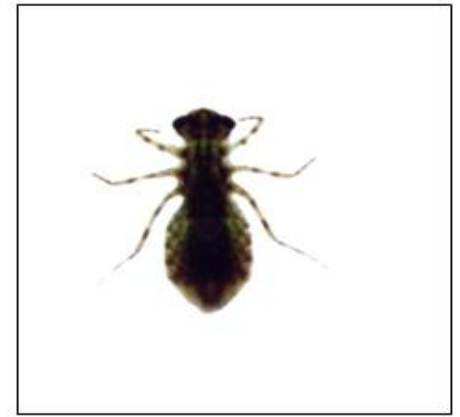

Fig.- 4: C. S. Servilia First instar Naiad

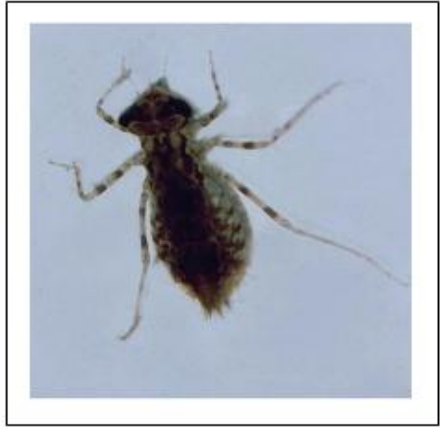

Fig.- 5: C. S. Servilia Last instar Naiad 